\title{
Social Network Development, Language Use, and Language Acquisition during Study Abroad: Arabic Language Learners' Perspectives
}

\author{
Dan P. Dewey \\ Brigham Young University
}

\section{R. Kirk Belnap \\ Brigham Young University}

\section{Rebecca Hillstrom \\ Brigham Young University}

Language learners and educators have subscribed to the belief that those who go abroad will have many opportunities to use the target language and will naturally become proficient. They also assume that language learners will develop relationships with native speakers allowing them to use the language and become more fluent, an assumption Pellegrino (Pellegrino, 1997, 1998) found to be held by study abroad participants. However, recent research has shown that students do not always use the language to the expected degree and that they often fall back on social relationships with native speakers of their own language (DeKeyser, 2007; Dewey, 2008; Polanyi, 1995; Rivers, 1998; Wilkinson, 1998a, 1998b).

Freed, Segalowitz, and Dewey (2004) found that study abroad participants used more English than French in their daily interactions during study abroad in France, and that study abroad learners used less French than students at home in an intensive language immersion setting. Learners in France were exposed to opportunities to use French but tended to speak with their fellow study abroad participants in English instead. Wilkinson (1998b) noted similar patterns and suggested, "The spontaneous formation of home culture 'islands' may actually have been the most efficient way for the students to keep from drowning in the French 'ocean' while they began to process the barrage of cultural differences and linguistic challenges faced on a daily basis" (p. 32). In contrast, James Coleman notes, "While L1 groups provide a secure base from which to risk-take linguistically, and a rest from L2 use, they may also pose the danger of reinforcing and concretizing what would otherwise be 
temporary reactions to setbacks: 'the French are rude' (or whatever) becomes a more entrenched belief each time it is rehearsed with compatriots, in letters home, or on Facebook, and this can in itself become an obstacle" (personal communication, April 6, 2010).

The homestay experience is commonly thought to be the greatest source for language use and social interaction. While this can be the case, research has also shown that students in these settings may not have regular opportunities for language use (Pellegrino, 1997, 1998; Rivers, 1998; Wilkinson, 1998a). Wilkinson (1996) found great variation in the homestay experience of study abroad participants in France, with some feeling embraced and forming strong social ties with their families and others feeling alienated and alone. Rivers (1998) suggested that some of his second language speakers of Russian, struggling with the challenges of speaking, retired to their rooms where they practiced reading Russian with the hope that they would develop the linguistic skills necessary to interact with their host families and others.

Outside of the homestay and classroom settings study abroad learners are able to interact with others by participating in clubs, part-time jobs, community service, social events, and more (Fraser, 2002; Pellegrino, 1997; Whitworth, 2006). Fraser (2002) found that learners who participated in a variety of community interactions (playing on football teams, participating in internships, playing in an orchestra, etc.) during study abroad in Germany demonstrated more linguistic development on measures of reading and writing proficiency than learners who participated in traditional classroom-oriented programs. Similarly, Whitworth (2006) found that engaging in school clubs, sports, and social activities outside of the classroom contributed to linguistic gains in French. Whitworth discovered that French television and radio were used to foster social networks with French natives allowing one learner, who listened to and watched broadcasts often, to engage in significant interactions with his host family and others.

Whitworth (2006) found that learners' genders and gender identities influenced their development of social networks during study abroad in France. One female student refused to conform to what she saw as social norms for French females, withdrawing from social circles where French women followed these norms, thereby limiting her interactions with native speakers. Another American woman, on the other hand, followed the stereotypes for French women as closely as she could and used these stereotyped roles to gain access to French social circles including both men and women. Siegal (1995) found similar patterns for female learners of Japanese as a second language in Japan.

D'Urso (1997) discovered that L1 cultural background for international students in the U.S. (individualism vs. collectivism) did not influence their 
ability to develop social networks during time abroad in the U.S. On the other hand, English proficiency level did influence this ability, with those having higher levels of proficiency developing stronger social networks. In a similar setting, Krywulak (1995) found that international students' social networks consisted of both fellow national and host national networks. Fellow national networks facilitated the transition to residence abroad by assisting with logistical issues such as finding housing, working out transportation, and registering for school, etc. These networks later inhibited students' linguistic development however. Host national networks, on the other hand, provided a source for developing professional, instrumental knowledge and linguistic development. Perkins (2004) suggested improving social networks for international students in the U.S., stating "a positive international-oriented social atmosphere could be fostered with proper coordination of the institution's formal and informal social support networks" (p. vi). Perkins noted the need to connect international students with domestic students, in particular during orientations, etc.

Knight and Schmidt-Rhinehart (2002) found that host families felt students adapted best and developed close ties with the family if they were open and less connected with family and friends back home. Host families felt this openness was more important to students' adaption and creation of family ties than their linguistic proficiency. Similarly, among Isabelli's (2001) study abroad participants in Argentina, those who showed the highest levels of motivation were more likely to form strong social networks and subsequently to develop stronger linguistic skills. Papatsiba (2006) found that Europeans studying abroad who were able to view their foreignness as a positive, and rethink their own identities and expectations of social interactions, were able to build successful relationships with locals.

In several studies learners who maintained strong ties with family and friends at home while abroad through email and telephone failed to create strong social networks and suffered linguistically. On the other hand, students who overcame the initial discomforts of cross-cultural interactions, and continued to use the language in spite of challenges and discomforts, usually developed social networks with native speakers and used the target language within these networks (Campbell, 1996; Levin, 2001; Whitworth, 2006). Maintaining strong ties with home and weaker ties with locals can have negative effects on linguistic gains during study abroad (Dewey, 2008).

In their book on language learners in study abroad settings, Dufon and Churchill (2006) highlight the complexities involved in carrying out meaningful social interactions in the target language:

The literature on individual differences suggests that the quality of interaction with $\mathrm{N}$ [ative] S[peaker]s is of prime importance in the acquisition 
process. It also indicates that the approach taken by L2 learners to this interaction can be mediated by their actual, or perceived, level of proficiency as well as situationally determined levels of anxiety and overall motivation. . . . $[\mathrm{H}]$ owever, the relationship between learners' engagement with the host context on the one hand, and increased motivation and proficiency and lower levels of anxiety on the other is not unidirectional, but rather mutually constituted. (p. 18).

Proficiency fosters, and can be fostered by, interaction and social relationships with others; motivation can be fostered by positive interactions but it is necessary to overcome negative interactions; anxiety can motivate one to improve personal language skills but can also inhibit language use. Dufon and Churchill continue, "Success in this endeavor [of building social networks] is related to learner characteristics such as openness, ability to make oneself socially salient, persistence in working to gain access, and tolerance for and attention to unmodified input." (p. 20). In short, while meaningful social interactions are important, there is not yet a definitive answer regarding what factors influence social interaction most, how best to prepare learners for these interactions, or how to foster interaction during residence abroad. Additional research is needed in this area.

There are mixed findings regarding connections between out-of-class language contact and second language proficiency development. Ginsberg and Miller (Ginsberg \& Miller, 2000; Miller \& Ginsberg, 1995) have found no systematic connections between out-of-class language use and gains on measures of language during study abroad. On the other hand, other studies (Dewey, 2008; Freed, Segalowitz, et al., 2004) have found some connection.

Oral proficiency development during study abroad has been investigated by several authors (Brecht, Davidson, \& Ginsberg, 1995; Freed, 1990, 1995a; Magnan, 1986; Milleret, 1990; Milleret, Stansfield, \& Kenyon, 1991; O’Connor, 1988; Opper, Teichler, \& Carlson, 1990; Yager, 1998). These studies tend to show significant gains in proficiency during study abroad, as measured by tools ranging from self assessment (Opper, et al., 1990) and native speaker judgments (Yager, 1998) to the American Council on the Teaching of Foreign Languages (ACTFL) Oral Proficiency Interview (Freed, 1990, 1995a; Magnan, 1986). Opper and her colleagues (1990) had students rate themselves on reading, writing, speaking, and listening abilities. While students reported greater confidence after study abroad in all areas, speaking and listening gains were more evident than reading and writing. Brecht and his colleagues (1995) found that learners who started at lower levels of proficiency initially (as measured by the Oral Proficiency Interview and the Interlanguage Roundtable scale) showed greater gains after study abroad than learners with 
higher levels of initial proficiency. On the other hand, they found that those with greater grammatical knowledge and reading abilities prior to study abroad tended to make more gains in oral proficiency than those with less. Freed (1995b) and Foltz (1991, cited in Freed, 1995b) determined that learners who studied abroad made greater gains on the Oral Proficiency Interview over time than learners who studied the language at home in a regular academic-year classroom setting. Overall, the studies indicate that study abroad can promote oral proficiency and confidence in one's speaking abilities.

The research above indicates the potential for study abroad to promote gains in L2 speaking abilities. It also highlights the need for additional research on amount and type of language use students experience during study abroad, the development of social networks while abroad, and connections between social networks, language use, and language development. In this study we focused on connections between social networks, language use, and language acquisition for learners of Arabic studying in Jordan and Morocco during a fourteen-week study abroad program. Specifically, our research questions regarding study abroad in Jordan and Morocco were:

1. How much time do learners spend using Arabic and English during study abroad?

2. What sorts of social networks are students able to develop during study abroad?

3. How much does learners' language proficiency develop during their time abroad?

4. How are language use, social networks, and language development connected for study abroad participants?

\section{Methods}

\section{Participants and Procedures}

To explore language use, social network development, and language acquisition during study abroad, we tested thirty learners of Arabic as a second language enrolled in study abroad programs in either Morocco or Jordan. The group included sixteen males and fourteen females, ages 19-28. All learners had studied Arabic for four fourteen-week semesters prior to studying abroad (five fifty-minute class periods per week). None had significant formal or informal experience learning Arabic before beginning their on-campus instruction. Students received between fifteen and twenty hours per week of Arabic language instruction while abroad. Measures of language use and of 
social network makeup were given following the study abroad experience, and measures of language proficiency were conducted both immediately before and after study abroad.

\section{Materials}

Language Contact Profile. Amount of language use was measured via a Web-based version of The Language Contact Profile (LCP), a survey created by Freed, Dewey, Segalowitz and Halter (2004). The Web-based LCP contained questions regarding the number of days per week and the number of hours per day students used Arabic or English. Several minor modifications were made to Freed's and the others' LCP. First, questions were ordered such that general questions regarding how much total time learners spent speaking, listening to, reading, and writing in Arabic and English were asked first. Following each of these four general questions regarding time spent reading, writing, speaking, and listening were a series of specific questions addressing time spent in activities such as speaking with host families, service personnel, or language instructors, reading magazines, newspapers, or novels, listening to radio, television, or other peoples' conversations, and writing personal notes or email messages, etc. The second modification was that questions were arranged and formatted to reduce redundant wording and yield a format more appropriate for Web-based delivery.

Using only the items on our Web-based LCP that asked for total amount of time spent reading, writing, listening to, and speaking Arabic and English, we calculated overall totals for each of these areas (a frequent criticism of the LCP is that if you add up all of the individual activities, these totals seem exaggerated). For each item in the LCP, the number of days spent using the language in the way listed was multiplied by the number of hours per day reported for the same item to determine an approximate total for the week. Approximate total number of hours in speaking, listening, reading, and writing were calculated using the one global estimate on the LCP for each skill (e.g., a single item, such as "On average, how much time (number of days per week and number of hours on those days) did you spend speaking, in Arabic, outside of class?"). It should be noted that the purpose of calculating totals for each activity was not to achieve an accurate estimate of number of hours total in the language. Rather, the purpose was to approximate the proportion or degree of time spent in each activity (i.e., if more hours are reported in one activity than another, the assumption is that it is a more frequently occurring activity, regardless of the difference in total hours).

Study Abroad Social Interaction Questionnaire. To analyze social networks, researchers have employed a variety of survey, interview, and observational 
tools (Knoke \& Yang, 2008; Milroy, 1987; Scott, 2000). For the purpose of this study, a new nine-item Study Abroad Social Interaction Questionnaire (SASIQ; see Appendix A) was designed to determine the size, durability, and intensity of study abroad participants' native Arabic speaker social networks (Scott, 2000). Size, measured by Item 1, is simply the number of native Arabic speakers an individual associates with. Durability, measured by Item 2, is the degree to which a social relationship is activated-how often a person associates with an individual (Scott, 2000). Since the focus of this study was largely language, participants were asked to indicate frequency of interaction both in English and Arabic. This led to two measures of durability: average frequency of use of Arabic with friends and acquaintances and average use of English with these same people. Intensity, measured by Item 3, is an indicator of how strong a relationship is; how close an individual feels to a person in their social network (Scott, 2000). The Friend-Acquaintance distinction in Item 3 of the SASIQ was based on Knoke and Yang (2008). For statistical analyses, intensity was calculated by dividing the number of people reported as friends by the number reported as either friends or acquaintances. Wording for Items 1,2 , and 3 was also partially drawn from the Montreal Index of Linguistic Integration (Segalowitz \& Ryder, 2006). To measure network Density, the degree of connections between people within one's network (Knoke \& Yang, 2008; Scott, 2000), the SASIQ asked students to arrange friends and acquaintances into social groups (Item 5). Three measures of Density were calculated: size of the largest social group under Item 5, average size of the groups listed, and average size of the two largest groups listed in the same item. These same values were calculated twice: once including the homestay family as a social group and once excluding the family. The host family was excluded the second time to remove the one group all students were automatically placed in from groups students sought out on their own. Finally, Dispersion, the number of social groups listed under Item 5, was calculated. The SASIQ also asked students how friendships were formed and what factors facilitated or inhibited the formation of friendships. Students further provided information regarding topics commonly discussed and topics avoided in conversation. Finally, the SASIQ asked participants to evaluate their own social patterns (Item 9) to allow us to control for general social tendencies, independent of language and cultural barriers, when considering the development of social networks.

Language Proficiency Measure. Proficiency was measured using a thenand-now self-assessment (Rohs \& Langone, 1997). Rohs and Langhone argue that a then-now approach is more accurate than a pre-/post- self-assessment approach because learners experience a response shift between pre- and posttesting. In other words, their standard of measurement at post-testing tends 
to be different from pre-testing, due to greater experience with the tasks being self-assessed. As Rohs and Langhone note, students engaging in then-now self-assessments are typically "evaluating themselves with the same standard of measurement or level of understanding on both their post-test responses (how they felt now) and how they felt before the program (then).” (p. 156). Selfassessment has frequently been used in study abroad research (see for example Dyson, 1988; Meara, 1994; Opper, et al., 1990; Teichler \& Maiworm, 1997), either as the sole measure of proficiency and linguistic gains or as a complement to other measures of proficiency. Given the relatively substantial amount of self-assessment data related to study abroad, results in this study can be readily compared with other similar work.

The Then-Now Survey was designed based on an oft-used self-assessment instrument by Clark (1981). The survey presents a number of tasks, ranging from simple to complex, and asks learners to rate their abilities to accomplish the tasks using the following scale: 0 -not at all; 1-with great difficulty; 2-with some difficulty; 3-easily; 4-quite easily. In addition to Clark's tasks, the survey also included items based on the ACTFL Speaking Proficiency Standards (Breiner-Sanders, Lowe, Miles, \& Swender, 2000)—items ranging from Novice-level abilities to Superior-level abilities (see survey in Appendix B for examples). Since only twenty-one of the participants completed all parts of the Then-Now Survey, only data from these twenty-one participants was used in the Then-Now analysis.

\section{Results}

The first research question addressed the amount of time learners spent using Arabic and English during their study abroad experience. Table 1 displays the number of hours students reported speaking, reading, writing, and listening to Arabic and English while abroad. Students recounted spending the most time speaking English and the second most speaking Arabic. In Arabic, frequency of language use was as follows (most to least): speaking, reading, listening, and writing. The same pattern was seen in English. Reported amount of time spent speaking, listening, and reading were similar in English and Arabic (i.e., no significant differences existed on paired sample t-tests). However, amount of time spent reading Arabic was significantly greater than amount of time spent reading English, $\mathrm{t}(28)=3.88, \mathrm{p}<.001, \mathrm{~d}=7.14$. Table 2 displays the ten most frequent activities reported in the Language Contact Profile, providing an overview of specific ways English and Arabic were used by learners. 
Dan P. Dewey, R. Kirk Belnap, Rebecca Hillstrom

Table 1. Reported Overall Number of Hours Spent Per Week Using Arabic and English

\begin{tabular}{lll}
\hline & Mean & SD \\
\hline Speaking Arabic & 21.0 & 9.8 \\
Speaking English & 26.2 & 12.3 \\
Reading Arabic & 17.0 & 7.7 \\
Reading English & 9.8 & 6.6 \\
Listening to Arabic & 17.9 & 12.9 \\
Listening to English & 19.0 & 11.1 \\
Writing Arabic & 9.1 & 5.3 \\
Writing English & 8.3 & 6.6 \\
\hline
\end{tabular}

Table 2. Number of Hours Reported Spent in Ten Frequent LCP Activities, Sorted from Highest (most hours) to Lowest (least number of hours)

\begin{tabular}{|c|c|c|c|}
\hline Activity & & Mean & SD \\
\hline 1. & Reading in Arabic for homework purposes & 13.8 & 6.02 \\
\hline 2. & Speaking English with native speakers of Arabic & 12.7 & 6.31 \\
\hline 3. & $\begin{array}{l}\text { Engaging in extended conversations with host family, } \\
\text { Arabic-speaking roommates, friends, or acquaintances } \\
\text { in Arabic }\end{array}$ & 12.6 & 8.25 \\
\hline 4. & Trying to catch other peoples' conversations in Arabic & 11.3 & 8.90 \\
\hline 5. & $\begin{array}{l}\text { Trying to use Arabic taught in class with others outside } \\
\text { of class }\end{array}$ & 11.2 & 6.27 \\
\hline 6. & $\begin{array}{l}\text { Using Arabic with people at home (host family, Arabic- } \\
\text { speaking roommates, etc.) }\end{array}$ & 10.3 & 10.37 \\
\hline 7. & $\begin{array}{l}\text { Using Arabic in superficial or brief exchanges (e.g., } \\
\text { greetings, "Please pass the salt," "I'm leaving," ordering } \\
\text { in a restaurant) }\end{array}$ & 8.6 & 5.38 \\
\hline 8. & $\begin{array}{l}\text { Bringing up in class for discussion linguistic items } \\
\text { encountered outside of class in Arabic. }\end{array}$ & 8.2 & 4.98 \\
\hline 9. & Writing homework assignments in Arabic & 8.0 & 4.33 \\
\hline 10. & Reading email or browsing the Internet (English) & 7.7 & 5.18 \\
\hline
\end{tabular}


The second research question focused on the nature of students' social networks. Table 3 displays means and standard deviations for each of the numeric measures of social networks. The largest social network consisted of twenty Arab friends and the smallest had only three. Since all students were assigned to live with host families, the host family was a social group provided by the program for all participants. Excluding the host family, social relationships were formed largely based on student initiative. Outside of the host family, the smallest social network was zero and the largest fifteen. Four participants reported having neither Acquaintances nor Friends outside of the homestay setting, while five participants indicated having ten or more Friends or Acquaintances outside of the host family. There was much variation in Size, with the standard deviation being approximately $45 \%$ of the mean when host families were included and $67.6 \%$ of the mean when host families were excluded.

Table 3. Descriptive Statistics for Measures of Participants' Social Networks

\begin{tabular}{|c|c|c|c|c|}
\hline & Minimum & Maximum & Mean & SD \\
\hline \multicolumn{5}{|l|}{ Size } \\
\hline $\begin{array}{l}\text { Number of Friends and } \\
\text { Acquaintances }\end{array}$ & 3 & 20 & 8.8 & 4.00 \\
\hline $\begin{array}{l}\text { Number of Friends and } \\
\text { Acquaintances Outside of Host } \\
\text { Family }\end{array}$ & 0 & 15 & 5.9 & 3.96 \\
\hline \multicolumn{5}{|l|}{ Durability } \\
\hline Frequency of Arabic Use & $\begin{array}{c}3 \\
\text { (Sometimes) }\end{array}$ & $\begin{array}{c}5 \\
\text { (Very Often) }\end{array}$ & 4.0 & 0.59 \\
\hline Frequency of English Use & $\begin{array}{c}2 \\
\text { (Rarely) }\end{array}$ & $\begin{array}{c}5 \\
\text { (Very Often) }\end{array}$ & 3.2 & 0.65 \\
\hline \multicolumn{5}{|l|}{ Intensity } \\
\hline Percent Friends & 0 & 100 & 60 & 24.1 \\
\hline Number Friends & 0 & 14 & 5.6 & 3.05 \\
\hline \multicolumn{5}{|l|}{ Density } \\
\hline Size of Largest Social Group & 1 & 6 & 3.5 & 1.57 \\
\hline Average Size of Social Groups & 1 & 6 & 2.4 & 1.01 \\
\hline Size of Two Largest Social Groups & 1 & 5.5 & 2.6 & 1.15 \\
\hline $\begin{array}{l}\text { Average Size of Social Groups } \\
\text { Excluding Host Family }\end{array}$ & 1 & 3.5 & 1.8 & 0.76 \\
\hline \multicolumn{5}{|l|}{ Dispersion } \\
\hline Number of Social Groups & 1 & 6 & 3.0 & 1.29 \\
\hline
\end{tabular}

Note. Statistics above are from the twenty-nine participants who completed the SASIQ. 
In terms of Durability, students tended to speak Arabic "Often" with friends and acquaintances and English "Sometimes." On average, 62\% of the students' social network consisted of "Friends" and 38\% "Acquaintances." Regarding Intensity, two participants reported having no Arab "Friends," but on average about $60 \%$ of the people in a learner's social network were Friends. Considerable variation was also seen in the other social network features.

Social groups tended to be rather small (average of 3.45 people per group), with the largest including six people and the smallest one person. Since host families were the largest social group for many students, measures of Density were smaller when host family numbers were excluded. The one measure of Density where variability was greatest was the average size of the two largest social groups outside of the host family. For that measure, the standard deviation was $80.2 \%$ of the mean. Variability was substantial for other measures as well, but not nearly as large as for this measure. Finally, Dispersion ranged from one social group (the host family) to six (the host family plus five others). Average Dispersion was 3.04 social groups.

The third research question addressed gains in language proficiency over study abroad. Pre- and post- self-evaluations of speaking abilities (Then-Now responses) were compared using a series of paired sample t-tests. T-test results, shown in Table 4 indicated significant gains in every aspect of the Then-Now self-assessment. Table 4 is organized from largest mean change to smallest. The areas where students indicated the greatest gains in speaking abilities tended to involve survival language (meeting personal and immediate social needs, obtaining and giving information by asking and answering questions, and responding to simple questions on the most common aspects of daily life) and aspects of speech that lower-level learners tend to struggle with (producing few errors, speaking fluently, and using a wide variety of vocabulary). The areas where students indicated the lowest gains were of two types. First, learners showed low gains in areas where a ceiling effect came into play: students started out fairly high and were therefore able to show fewer gains in these areas (giving biographical information about self, describing present job, studies, interests, etc.). The second type of response where learners showed the fewest gains involved very challenging areas_-areas associated with Superior or Advanced level proficiency on the ACTFL scale (speculating and presenting hypotheses, speaking in Arabic without having to substitute English or guess excessively how to say something, dealing with linguistically unfamiliar situations, stating and supporting opinions on controversial topics, etc.). 


\begin{tabular}{|c|c|c|c|c|c|}
\hline Task Description & $\begin{array}{l}\text { Mean } \\
\text { Change }\end{array}$ & s.d. & df & $\mathrm{t}$ & $\mathrm{p}$ \\
\hline $\begin{array}{l}\text { Satisfy simple personal needs and social } \\
\text { demands to survive in an Arabic-speaking } \\
\text { setting }\end{array}$ & 1.571 & 0.746 & 20 & 9.648 & $<.0001$ \\
\hline $\begin{array}{l}\text { Speak without producing errors that might } \\
\text { disturb or distract a native listener. }\end{array}$ & 1.524 & 0.928 & 20 & 7.522 & $<.0001$ \\
\hline Speak fluently without interruption. & 1.429 & 0.87 & 20 & 7.524 & $<.0001$ \\
\hline $\begin{array}{l}\text { Obtain and give information by asking and } \\
\text { answering questions }\end{array}$ & 1.381 & 0.805 & 20 & 7.864 & $<.0001$ \\
\hline $\begin{array}{l}\text { Use a wide variety of vocabulary to express } \\
\text { your thoughts without getting hung up on } \\
\text { words (i.e., not being able to find the word } \\
\text { you need to say what you want to say) }\end{array}$ & 1.381 & 0.669 & 20 & 9.459 & $<.0001$ \\
\hline $\begin{array}{l}\text { Respond to simple questions on the most } \\
\text { common aspects of daily life }\end{array}$ & 1.286 & 0.784 & 20 & 7.517 & $<.0001$ \\
\hline $\begin{array}{l}\text { Deal with complications in situations (e.g., } \\
\text { situations where the other person in the } \\
\text { conversation doesn't say what you expect or } \\
\text { behaves outside of your expectations). }\end{array}$ & 1.286 & 0.845 & 20 & 6.971 & $<.0001$ \\
\hline $\begin{array}{l}\text { Participate actively in conversations in most } \\
\text { informal and some formal settings on topics of } \\
\text { personal and public interest }\end{array}$ & 1.286 & 0.784 & 20 & 7.517 & $<.0001$ \\
\hline $\begin{array}{l}\text { Describe events and objects in the past, } \\
\text { present, and future }\end{array}$ & 1.238 & 0.539 & 20 & 10.527 & $<.0001$ \\
\hline $\begin{array}{l}\text { Describe college life to another person in } \\
\text { detail. }\end{array}$ & 1.19 & 0.75 & 20 & 7.278 & $<.0001$ \\
\hline $\begin{array}{l}\text { Talk about current political issues with an } \\
\text { educated native speaker. }\end{array}$ & 1.19 & 0.68 & 20 & 8.027 & $<.0001$ \\
\hline $\begin{array}{l}\text { Say simple greetings, courtesy phrases like } \\
\text { "thank you," and use appropriate language } \\
\text { when taking leave. }\end{array}$ & 1.143 & 0.727 & 20 & 7.204 & $<.0001$ \\
\hline $\begin{array}{l}\text { Speak about abstract topics, connecting ideas } \\
\text { logically and smoothly. }\end{array}$ & 1.143 & 0.727 & 20 & 7.204 & $<.0001$ \\
\hline $\begin{array}{l}\text { Express nearly any idea you could express in } \\
\text { your native language. }\end{array}$ & 1.143 & 0.655 & 20 & 8 & $<.0001$ \\
\hline $\begin{array}{l}\text { Tell what you plan to be doing } 5 \text { or more } \\
\text { years from now. }\end{array}$ & 1.143 & 0.793 & 20 & 6.606 & $<.0001$ \\
\hline $\begin{array}{l}\text { State and support with examples opinions } \\
\text { about controversial topics. }\end{array}$ & 1.143 & 0.793 & 20 & 6.606 & $<.0001$ \\
\hline $\begin{array}{l}\text { Deal with linguistically unfamiliar situations } \\
\text { (situations never before encountered in } \\
\text { Arabic). } \\
\text { Describe your present job, studies (classes, } \\
\text { major, etc.), and professional and academic }\end{array}$ & 1.095 & 0.7 & 20 & 7.167 & $<.0001$ \\
\hline
\end{tabular}
interests. 


\begin{tabular}{lccccc}
\hline Task Description & $\begin{array}{c}\text { Mean } \\
\text { Change }\end{array}$ & s.d. & df & t & $\mathrm{p}$ \\
\hline $\begin{array}{l}\text { Speak in Arabic without having to substitute } \\
\begin{array}{l}\text { English words or guess excessively how to } \\
\text { say something. }\end{array}\end{array}$ 0.952 & 0.805 & 20 & 5.423 & $<.0001$ \\
$\begin{array}{l}\text { Give simple biographical information about } \\
\text { self (name, age, composition of family, etc.). }\end{array}$ & 0.952 & 0.669 & 20 & 6.523 & $<.0001$ \\
\begin{tabular}{l} 
Speculate and present hypotheses \\
\hline
\end{tabular} & 0.857 & 0.727 & 20 & 5.403 & $<.0001$ \\
\hline
\end{tabular}

The fourth research question addresses relationships between language use, social networking, and language development. Regression analysis was conducted to determine predictors of language development over time (i.e., differences between pre/then and post/now results). The regression equation predicted over eighty percent of the variance in self-perceived gains over time, adjusted $\mathrm{R}^{2}=.808, \mathrm{~F}(3,15)=26.2, \mathrm{p}<.0001$. The greater the English proficiency of the learners' Arab friends, the more gains they were likely to show in Arabic proficiency $\left(B=1.02, \mathrm{SE}_{\mathrm{B}}=.105, \beta=1.16, \mathrm{p}<.0001\right)$. Similarly, the stronger their relationship with their Arab friends, the higher their gains $\left(\mathrm{B}=1.17, \mathrm{SE}_{\mathrm{B}}=.273, \beta=.50, \mathrm{p}<.001\right)$, and the more they interacted with people other than the individuals they listed as friends and acquaintances (including their homestay family), the more likely they were to show gains in proficiency $\left(\mathrm{B}=.07, \mathrm{SE}_{\mathrm{B}}=.019, \beta=.44, \mathrm{p}<.002\right)$.

\section{Discussion}

Students reported spending just as much time speaking, listening to, and writing English as they did Arabic, but more time reading Arabic than English. This last finding is supported by the fact that the highest specific area of language use was time spent reading in Arabic for homework purposes. The nature of students' academic experience, with intensive language learning being a major emphasis, helps explain the large amount of Arabic reading. Relative lack of availability of printed English materials may have influenced reading habits as well.

The tendency for Americans going abroad to use English as much as or more than the target language has been documented in other studies as well (Freed, 1990, 1995a; Freed, Segalowitz, et al., 2004). It is at least encouraging that learners in our study spoke nearly as much Arabic as English, contrary to other studies (e.g., Freed et al., 2004).

It is noteworthy that the second highest specific area of language use was time spent speaking English with Arabs. Much of the discussion of English language use in previous studies has highlighted the use of English among 
fellow study abroad participants (Freed, Segalowitz, et al., 2004; Wilkinson, 1998a). It is again encouraging that the learners in this study reported speaking extensively with native speakers of Arabic, even if it was in English. It is also important to note that the third highest individual area of language use was engaging in extended conversations with native friends and acquaintances in Arabic. This provides further evidence that interactions with native speakers occurred regularly, both in English and in Arabic, for this group.

One possible explanation for the use of both English and Arabic with Arabs is that the study abroad program recommended using English to access Arabic: learners were encouraged to offer to exchange tutoring and speech practice in English for equal time being tutored in and using Arabic. Poststudy interview and questionnaire responses indicated that learners felt English was a good tool for gaining access to Arabic. For example, one student noted, "So I posted a bunch of fliers up around campus that said that I will trade you an hour of Arabic tutoring from you, for an hour of English tutoring for me. I got a ton of calls. It was the best thing that ever happened to me." Similarly, another student stated, "English did help lead to using Arabic more. A lot of these people wanted help with English. Other friendships kind of died out, but helping them with English helped longer relationships to form.” Regarding the use of Arabic as a tool for social networking and language use, another student said, "English served as a ticket to Arabic in a way. I got in with Arabs by speaking English with them. Then once they got around each other, they'd speak Arabic. I got to listen to them and, once in a while they'd speak English when talking directly to me, but usually unless I didn't understand they spoke Arabic. As long as I was with a group of them, I got Arabic."

Students reported engaging in extended conversations in Arabic more frequently than superficial exchanges. Past research (e.g., Wilkinson, 1998a) has shown that many of the conversations learners have with natives during study abroad are typically superficial, involving minimal opportunities to practice the language beyond short, simple exchanges. Wilkinson (1998a) found that learners in homestay settings often engaged in rote conversations with their families rather than in-depth extended conversations. To facilitate language acquisition, Yager (1998) has emphasized that students need to go beyond these rote conversations, finding and seizing opportunities to engage in deeper interaction rather than superficial exchanges. Lybeck's (2002) participants noted that it took time to develop the types of relationships with Norwegians where they were able to have deeper personal relationships; relationships that allowed them to talk about less superficial things and have more meaningful exchanges. It is, therefore, noteworthy that the participants in our study were able to engage in extended conversation more than superficial after only 
fourteen weeks abroad. We are currently engaged in further exploration of the nature of the study abroad program, of strategies students employed that allowed them to participate in more extended conversations, and of the actual nature of the learner conversations. This exploration includes analysis of learner journal entries written during study abroad and of post-study interviews with students and program directors. It also includes observing and recording actual conversations learners have while abroad. As Kinginger (2009) and Dufon and Churchill (2006) suggest, while figures such as the number of hours spent in a given activity can be revealing, gaining a comprehensive picture of the complex nature of the study abroad experience requires more detailed qualitative analyses of the study abroad experience. We hope that our qualitative analyses will contribute significantly to our understanding of what learners defined as extended conversations, what factors facilitated these conversations, and how beneficial they were in terms of language development. This analysis suggests differences between programs in the quality of interactions during homestay experiences and differences across genders in the types of social interactions engaged in.

The fifth and eighth most frequent ways of using language involved connections between the classroom and out-of-class language contact, connections Wilkinson (2002) also found to be rather strong. Wilkinson's students took classroom discourse norms and expected to use them outside of class in their interactions with others. Our study does not address the nature of interactions outside of class, but it does indicate students tried to use language taught in class and brought back questions to class based on their interactions outside of class. Further research could explore in greater depth the nature of the language students take from class and use in out-of-class interactions and the influence classroom discourse has on out-of-class interactions.

Writing in Arabic for homework purposes was the ninth most common activity students reported engaging in. While the benefits of writing in terms of oral proficiency are not entirely clear, there has been some research (Freed, Segalowitz, et al., 2004) indicating writing to be connected with speaking development during study abroad, and there is other evidence that writing can facilitate vocabulary development while abroad (Dewey, 2008). Freed et al. found writing to be the sole significant predictor of oral fluency development for learners of French in Paris for a semester. They noted:

Perhaps these students benefited from an effect that Swain (1993, 2000) has articulated as the basis of her "output" hypothesis — that the act of producing output forces the learner to process language more deeply. This would certainly be true of report writing. In addition, sustained activity in looking up information in a variety of sources could be expected to lead 
to automatization of important linguistic constructions through frequent encounters with those constructions (Gatbonton \& Segalowitz, 1988; Segalowitz \& Gatbonton, 1995) and to greater certainty about how to use them. This experience might thus be reflected in speech that is less hesitant and freer of self-induced interruptions." (p. 295)

In short, while evidence documenting the benefits of writing during study abroad is minimal, it does suggest a positive relationship, hinting that those who spend time writing are likely to benefit in some way linguistically. PérezCial and Juan-Garau (2009) found that learners made significant gains in L2 writing skills while abroad and suggested that oral practice and automatization of $\mathrm{L} 2$ rules through use are key factors that, in addition to writing practice, can influence L2 writing development during study abroad.

The tenth most common activity students engaged in was reading email and browsing the Internet in English. Dewey (2008) found that learners who spent more time reading email and browsing the Internet in English tended to acquire less vocabulary knowledge than those who spent less. While no connections between Internet use and language gains were found in this study, the fact that Internet use was one of the ten most frequent activities, combined with Dewey's finding, suggest that this variable is worth considering in future studies. Such studies could include an analysis of the types of activities learners engage in while using the Internet and the relationships between these activities and language development, social network growth, and attitudes and motivation. It may be that there is some psychological benefit to using the Internet as a pressure release valve. Wilkinson (1998b) has suggested that speaking in English with fellow study abroad participants may be a way to avoid being overwhelmed by the cultural and linguistic divides they experience. It could be that using the Internet to "converse" with others in English serves a similar purpose.

\section{Social Network Development}

There was a large amount of variation in social network development for our participants. All students listed homestay family members as friends or acquaintances, but the range in network size beyond the host family was substantial. Variation, as measured by standard deviation, was typically between approximately $35 \%$ and $80 \%$ of the mean for the various social network measures. This variability matches patterns of large amounts of variability in language use and language acquisition in previous study abroad research (Coleman, 1998; Freed, 1995a; Huebner, 1995). Many have asserted that attitudes and motivation are key factors contributing to variation in the formation of networks of friends (Campbell, 1996; Isabelli, 2001; Knight \& 
Schmidt-Rinehart, 2002; Levin, 2001; Papatsiba, 2006; Whitworth, 2006). Future research on social network development could explore attitudes and motivation in greater detail and could combine both quantitative measure such as ours and qualitative measures such as journals, ethnographic observations, and participant interviews.

The largest social network consisted of twenty Arabs (fifteen outside of the host family). While the survey allowed participants to list up to twenty friends and acquaintances, only one person listed twenty people. The average Size was approaching nine people including the host family and six excluding the family. It is encouraging to see that learners typically became acquainted and used Arabic with this many Arabs, but it is disconcerting to see that some students developed few, if any, friendships outside of the host family setting (a social group imposed by the program structure). We will address factors contributing to size in a future paper.

In terms of social network Durability, students tended to speak Arabic often with their Arab friends, in spite of sometimes using English with these same people. Arabic language use was perceived to be greater than English with Arabs. The level of network Intensity was fairly high, with $62 \%$ of students' network members being labeled Friends rather than simply Acquaintances. It is encouraging that students are developing deeper relationships with Arabs and using Arabic on a fairly regular basis with these people. Further research regarding the nature of these relationships, how they are developed, and how they influence language acquisition and use would be valuable.

Measures of Density showed that the size of learners' individual social groups (as opposed to overall network size) was generally fairly small, typically including only two or three people. Host families were the largest social group for many of the participants, contributing greatly to the overall network size.

The importance of the host family in terms of social networks and interacting with Arabs outside of the classroom is apparent in this data. With four learners developing no social relationships outside of the host family and a large percentage having few non-homestay friends or acquaintances, it appears that student relied heavily on these relationships and did not tap other sources extensively. It might also be that greater program intervention is necessary to increase the size of students' social networks outside of the host family. Some possibilities might include placing learners in internships, providing health club memberships, or requiring memberships in university clubs. This might be particularly important if interactions with host families are not as productive socially and linguistically as expected. In the homestay situations described here, there were numerous examples where this was the case. Our study did not focus on the nature of interactions with the host families, 
but other research (Wilkinson, 1998a) has shown that while some homestay experiences can involve extensive interaction in the target language, others can involve little interaction. It is possible those with small non-homestay networks were having enough interaction within their host families that they didn't feel the need for extensive interactions with Arabs outside of the families. Another possibility is that they were having negative experiences and were therefore discouraged about interacting with others. Motivation may have also played a major role for, as Whitworth (2006) has pointed out, it is often necessary for learners to push beyond their comfort zones to develop friendships. Learners with few or no non-host friends or acquaintances could have simply had greater difficulty stretching beyond their comfort zones to interact with Arabs outside of the classroom.

Overall, while the social network figures are relatively small, it is encouraging that students seem to be engaging in social interactions with Arabic speakers. Aside from the few who had no social groups outside of the host family, participants tended to be engaged in at least one social group, even though the size of these groups was rather small. It is possible that these social groups were larger than depicted by the survey itself but that learners only listed the people they felt were acquaintances or friends. It is likely that they knew some by face but not by name. Perhaps the Study Abroad Social Interaction Questionnaire could be revised to allow students to list the number of participants in a group rather than listing all of the names of members, since students may have been experiencing greater Arabic language interaction within the groups than the current numbers indicate.

\section{Language Development}

Matching patterns seen in other study abroad research (Lapkin, Hart, \& Swain, 1995; Meara, 1994; Opper, et al., 1990; Teichler \& Maiworm, 1997), we found that learners perceived significant gains in their speaking abilities while abroad. One finding we believe to be unique to our study is that learners felt they made the greatest gains in areas related to survival skills and the lowest gains, though still significant, in more challenging areas involving discussion of abstract topics, speculating and hypothesizing, dealing with linguistically unfamiliar situations, etc. These results make sense intuitively, since we assume learners who go abroad will frequently encounter survival situations. Discussion of abstract topics, presenting and defending opinions, etc., may occur more frequently than at home, but such discussions are likely less frequent than the day-to-day survival experiences. It is also possible that the frequency of discussing such abstract topics can be greater in the classroom setting than in out-of-class environments. Comparisons of classroom and outof-class discourse patterns such as McMeekin's (2006) could be beneficial in 
this respect.

Most of the more challenging skills in our self-assessment are related to the higher levels of the ACTFL Proficiency Scale. Previous research on study abroad involving the Oral Proficiency Interview (OPI) has indicated that those who start at lower levels on the OPI are likely to show greater gains. It therefore makes sense that if students perceive greater gains on skills more typically associated with the lower end of the ACTFL scale, they are likely to master these skills and move up on the OPI. Students who have shown mastery of these lower level skills may have greater difficulty moving up the scale, since doing so requires higher level skills, skills they gain less in their self-assessments (see Pérez-Vidal \& Juan-Garau, 2009 for a discussion of similar patterns in writing development during study abroad). Our use of more discrete categories rather than a holistic score allows us to analyze areas of growth in greater depth and to determine which areas might be more typically associated with the study abroad experience. The fact that students perceive fewer gains at skills associated with Advanced and Superior level speech might also help to explain the ceiling effect discussed in the study abroad literature, students at higher levels show little gain on the OPI and other similar measures (Brecht, et al., 1995; Coleman, 1998; Freed, 1998; Lapkin, et al., 1995; Milleret, 1990).

As Kinginger (2009) points out, we have yet to learn much about the nature of interactions students engage in during their time abroad. Our study shows that learners feel more confident about certain types of interactions than others, but it does not show what types of interactions they actually engage in or how various types of interactions can influence language acquisition.

\section{Interactions between Language Use, Social Networks, and Language Gains}

The data indicate that the strongest predictor of language gains was the English language proficiency of participants' Arab friends and acquaintances. As discussed previously, participants regularly reported that English served as a tool for gaining entrance into social circles and for having conversation with Arabs. While it could seem surprising that proficiency was a significant predictor (i.e., the higher the English proficiency of their friends, the greater their gains in Arabic) it is noteworthy that frequency of use of English with Arabs was highly correlated with the English language proficiency of Arab friends, and was therefore removed from the model. When proficiency was removed, a similar model was generated, but that model only predicted approximately $60 \%$ of the variance. In short, English proficiency and frequency of use were both positively connected with Arabic language development. This was in spite of the fact that some learners also reported that locals wanted to 
practice English with them and were therefore less willing to speak Arabic. It may be that the level of English proficiency and/or experience abroad are factors determining which language a local chooses to use when conversing with a study abroad participant.

A second important predictor of language gains was Intensity, or level of friendship. The greater the students' level of friendship with Arabs the higher their gains in Arabic were likely to be. This indicates that it might not be just a matter of how many friends or acquaintances a person makes in the target culture, but rather the level of friendship they develop. Deeper relationships may lead to conversations that require higher levels of language proficiency, as feelings, opinions, abstract topics, etc. are discussed. Furthermore, it is possible that when people develop deeper friendships they gain access to experiences they might not otherwise have. For example, one student reported being invited into the home of an Arab friend after getting to know him better and crossing the threshold from acquaintance to friend. Another student reported that he was invited to accompany an Arab friend to other Arab's homes and to a variety of social events after getting to know him better. While it is hard to draw broad conclusions based on this data, the relationship between level of friendship and language gains certainly indicates that this topic would be worth exploring in greater detail. Kinginger (2009) suggests deeper investigation of "learners' interactive positioning in language socialization, the stances they adopt, the nature of their interactions, and the qualities of their evolving communicative repertoires" (p. 204), citing Block (2003, pg. 138), who recommends, "an attempt to reconstruct detailed life stories of learners hand-in-hand with an interest in linguistic development over time." The study of the depth of social relationships developed by students and its connection with language use and acquisition would go hand-in-hand with the type of research Kinginger recommends. It may be that developing deeper social relationships depends on learner attitudes and motivation (cf. Dufon and Churchill, 2006). This relationship is likely a complex, symbiotic one, however. Deeper relationships could decrease anxiety in speaking and fear of loss of face, thus increasing confidence and motivation to speak. Matthews (1995) found that women were more comfortable interacting in smaller groups of Russians (typically two or three women) while studying abroad in Russia than men, who engaged well with larger groups and mixed groups of Russian males and females. This suggests gender may also come into play in determining the depth of relationships and types of conversations learners can have. Connections between attitudes, motivation, social relationships, language use, and language acquisition are worth exploring further.

Amount of time spent speaking with people outside of one's host family 
and other established social circles also factored into the regression model. While this might seem to contradict the discovery of a connection between level of friendship and language acquisition, it can also be seen as complementary. The degree of the relationship between language gains and language use with people outside of one's social circle is not nearly as high as the degree for level of friendship. In other words, it appears that the greatest benefit linguistically comes from interacting with close friends and that this is supplemented by interaction with people outside of one's normal social circle. One oftmentioned example of benefitting from interactions with Arabs outside a student's social circle was speaking with taxi drivers. In Jordan, taxi drivers are often well-educated individuals who can provide a wealth of information. Students regularly mentioned having lengthy and interesting conversations with taxi drivers in Arabic. It is difficult to make broad conclusions based on our data, but the results do suggest it could be fruitful to further explore the nature of conversations with passing acquaintances and the contributions of these conversations to language development.

As mentioned earlier, Whitworth (2006), Isabeli-Garcia (2006), and Polanyi (1995) have shown that gender is an important variable to consider in study abroad research. The issue of gender was not addressed in this paper (though statistical analyses showed no significant differences in any area of our surveys between males and females). Qualitative data gathered as part of this study do show some differences between the experiences of male and female participants, however. These differences will be addressed in a later paper. We will also address the influence of program interventions (c.f. Perkins, 2004) in another paper.

Another limitation of this study is that we did not address the possible contributions of learners' initial language proficiency to social network development and language use. D'Urso (1997) found participants' language proficiency to be an important factor influencing the development of social networks with native speakers.

\section{Conclusion}

In this study, we explored language use during study abroad in Morocco and Jordan. We found that learners largely used English and Arabic to the same degree. We also found that the English language seemed to serve as a key to open the door to opportunities to use Arabic. The study abroad programs involved in this research encouraged students to use English to gain access to Arabic by serving as tutors and then being tutored. This may have been the key factor contributing to our finding, but our limited knowledge of the settings where English and Arabic were used prevents us from making solid 
conclusions in this respect. Further research needs to examine the types of interactions learners engage in and how English and the local language are used in such interactions.

Participants in this study were able to develop social networks with native speakers. However, those networks were generally small and limited, particularly outside of the homestay setting. The SASIQ, tool used to analyze these networks, provided useful information regarding the nature of students' social networks and one specific aspect of that survey, Intensity (degree of friendship), was particularly informative. Further use of this and other measures to investigate social network development and connections with language use and acquisition could be fruitful.

The Then-Now Survey used in this study provided informative data regarding specific aspects of language where learners perceived themselves making gains during study abroad. It appears that learners acquire confidence in their abilities to carry out many of the day-to-day tasks associated with living abroad. They also report gains in areas involving more complex linguistic tasks, but these gains are not as large. By breaking down speaking proficiency into specific tasks, we found benefits specific to study abroad that would not have likely been seen in standardized test scores alone. To follow up on this research, one could conduct more objective evaluations of abilities such as those described in the Then-Now Survey to determine whether students perform better over study abroad on these areas.

There was much variation in all of the data collected for this study. Doubtless, the quantitative analyses reported here have failed to bring out insights that would add a great deal to our understanding of these students' language learning experience. In our own work (Bown, Dewey, Belnap, \& Shelley, 2012; Dewey, Ring, Gardner, \& Belnap, to appear), we have included qualitative methods such as ethnographic observation, journaling, and interviewing, hoping to further our understanding of issues related to language use, social network development, and the language acquisition process. The addition of qualitative methods such as ethnographic observation, journaling, and interviewing could further our understanding of issues related to language use, social network development, and the language acquisition process.

Overall, this study sheds light on how learners use the target language while abroad, who they interact with, how they perceive their language gains, and how language use, social networking, and language acquisition are connected. While the study has many limitations, it provides insights regarding language use in two Arabic cultures, allowing for cross-linguistic comparisons with cultures more frequently researched. It also brings tools used in social network research into a study of language acquisition, showing some potential 
for these tools to facilitate understanding of the language acquisition process and the study abroad experience. Future research can be developed based on the tools used and findings reported in this study.

\section{Acknowledgements}

The authors wish to thank Spencer Ring and the anonymous reviewers, who provided valuable feedback on this article. They are also grateful for support from the Brigham Young University College of Humanities and from the U.S. Department of Education (P017A080087).

\section{References}

Bown, J., Dewey, D.P., Belnap, R.K, \& Shelley, H. (2012, March). Study abroad as a gendered experience: American women in Egypt. Presentation given at the annual meeting of the American Association for Applied Linguistics, Boston, MA.

Brecht, R. D., Davidson, D. E., \& Ginsberg, R. B. (1995). Predictors of foreign language gain during study abroad. In B. F. Freed (Ed.), Second language acquisition in a study abroad context. (pp. 37-66). Amsterdam, The Netherlands: John Benjamins Publishing Co.

Breiner-Sanders, K., Lowe, P., Miles, J., \& Swender, E. (2000). ACTFL proficiency guidelines: Speaking_revised 1999. Foreign Language Annals, 33, 13-18.

Campbell, C. (1996). Socializing with the teachers and prior language learning experience: A diary study. In K. M. Bailey \& D. Nunan (Eds.), Voices from the classroom (pp. 201-223). New York: Cambridge University Press.

Clark, J. D. (1981). Language. In T. D. Barrows (Ed.), College students' knowledge and beliefs: A survey of global understanding. Princeton, NJ: Educational Testing Service.

Coleman, J. S. (1998). Language learning and study abroad: The European perspective. Frontiers: The Interdisciplinary Jounral of Study Abroad, 4. Retrieved from http://www.frontiersjournal.com/issues/vol4/vol407_Coleman.htm

Dewey, D. P., Ring, S., Gardner, D., \& Belnap, R. K. (forthcoming). Social network formation and development during study abroad in the Middle East. System: An International Journal of Educational Technology and Applied Linguistics.D'Urso, T. (1997). Direct and mediating effects of individualism-collectivism orientation and social support on international students' adjustment. Unpublished PhD Dissertation, 
Hofstra University, Hempstead, NY.

DeKeyser, R. M. (2007). Practice in a second language: Perspectives from applied linguistics and cognitive psychology. Cambridge: Cambridge University Press.

Dewey, D. P. (2008). Japanese vocabulary acquisition by learners in three contexts. Fontiers: The Interdisciplinary Journal of Study Abroad, 15(Winter), 127-148.

Dufon, M. A., \& Churchill, E. (2006). Evolving threads in study abroad research. In M. A. Dufon \& E. Churchill (Eds.), Language learners in study abroad contexts (pp. 1-30). Buffalo, NY: Multilingual Matters.

Dyson, P. (1988). The year abroad: Report for the Central Bureau for Educational Visits and Exchanges. Oxford: Oxford University Language Teaching Centre.

Fraser, C. C. (2002). Study abroad: An attempt to measure the gains. German as a Foreign Language Journal, 1, 45-65.

Freed, B. F. (1990). Language Learning in a Study Abroad Context: The Effects of Interactive and Noninteractive Out-of-Class Contact on Grammatical Achievement and Oral Proficiency. Georgetown University Round Table on Languages and Linguistics, 459-477.

Freed, B. F. (1995a). Second language acquisition in a study abroad context. Amsterdam, The Netherlands: John Benjamins Co.

Freed, B. F. (1995b). What makes us think that students who study abroad become fluent? In B. F. Freed (Ed.), Second language acquisition in a study abroad context (pp. 123-148). Amsterdam, The Netherlands: John Benjamins Publishing Co, 1995.

Freed, B. F. (1998). An overview of issues and research in language learning in a study abroad setting. Frontiers, 4(Fall), 31-60.

Freed, B. F., Dewey, D. P., Segalowitz, N., \& Halter, R. (2004). The Language Contact Profile. Studies in Second Language Acquisition, 26, 349-356.

Freed, B. F., Segalowitz, N., \& Dewey, D. P. (2004). Context of learning and second language fluency in French: Comparing regular classroom, study abroad, and intensive domestic immersion programs. Studies in Second Language Acquisition, 26, 275-301.

Ginsberg, R. B., \& Miller, L. (2000). What do they do? Activities of students during study abroad. In R. D. Lambert \& E. Shohamy (Eds.), Language policy and pedagogy: Essays in honor of A. Ronald Walton. Philadelphia: John Benjamins.

Huebner, T. (1995). The effects of overseas language programs: Report on a case study of an intensive Japanese course. In B. F. Freed (Ed.), (pp. 
171-193). Amsterdam, The Netherlands: John Benjamins Publishing Co.

Isabelli, C. L. (2001). Motivation and Extended Interaction in the Study Abroad Context: Factors in the Development of Spanish Language Accuracy and Communication Skills. Dissertation Abstracts International, A: The Humanities and Social Sciences, 61(11), 4362-A.

Isabelli-García, C., (2006). Study abroad social networks, motivation and attitudes: Implications for second language acquisition. In Churchill, E., $\&$ DuFon, M.A. (Eds.), Language learners in study abroad contexts (pp. 231-258). Buffalo, NY, Multilingual Matters.

Kinginger, C. (2009). Language learning and study abroad: A critical reading of research. London: Pallgrave Macmillan.

Knight, S. M., \& Schmidt-Rinehart, B. C. (2002). Enhancing the homestay: Study abroad from the host family's perspective. Foreign Language Annals, 35, 190-201.

Knoke, D., \& Yang, S. (2008). Social Network Analysis (2nd ed.). Los Angeles: Sage Publications.

Krywulak, W. E. (1995). The social adjustment of international students attending McMaster University. McMaster University, Hamilton, Ontario.

Lapkin, S., Hart, D., \& Swain, M. (1995). A Canadian interprovincial exchange: Evaluating the linguistic impact of a three-month stay in Quebec. In B. F. Freed (Ed.), Second language acquisition in a study abroad context (pp. 67-94). Amsterdam, The Netherlands: John Benjamins Co.

Levin, D. M. (2001). Language learners' sociocultural interaction in a study abroad context. Indiana University, Bloomington, IN.

Lybeck, K. (2002). Cultural identification and second language pronunciation of Americans in Norway. The Modern Language Journal, 86(2), 174-191.

Magnan, S. S. (1986). Assessing speaking proficiency in the undergraduate curriculum: Data from French. Foreign Language Annals, 19(5), 429438.

Matthew, S. (1995). Behavior during study abroad: Can the differences between men and women in listening comprehension gain during study abroad be explained by behavior? Unpublished PhD Dissertation, Bryn Mawr College, Bryn Mawr, PA.

McMeekin, A. (2006). Negotiation in a Japanese study abroad setting. In M. A. Dufon \& E. Churchill (Eds.), Language learners in study abroad contexts (pp. 177-202). Buffalo, NY: Multilingual Matters. 
Meara, P. (1994). The year abroad and its effects. Language Learning Journal, 10(Sept), 32-38.

Miller, L., \& Ginsberg, R. B. (1995). Folklinguistic theories of language learning. In B. F. Freed (Ed.), Second language acquisition in a study abroad context (pp. 293-315). Amsterdam, The Netherlands: John Benjamins Co.

Milleret, M. (1990). Evaluation and the Summer Language Program Abroad: A Review Essay. The Modern Language Journal, 74(4), 483-488.

Milleret, M., Stansfield, C. W., \& Kenyon, D. M. (1991). The Validity of the Portuguese Speaking Test for Use in a Summer Study Abroad Program. Hispania, 74(3), 778-787.

Milroy, L. (1987). Language and social networks. Oxford: Basil Blackwell. O'Connor, N. (1988). Oral proficiency testing of junior year abroad:

Implications for the undergraduate curriculum. Paper presented at the Annual Meeting of the Modern Language Association.

Opper, S., Teichler, U., \& Carlson, J. (Eds.). (1990). Impact of study abroad programmes on students and graduates. London: Jessica Kingsley. Papatsiba, L. (2006). Study abroad and experiences of cultural distance and proximity: French Erasmus students. In M. Byram \& A. Feng (Eds.), Living and studying abroad: Research and practice. Clevedon, England: Multilingual Matters.

Pellegrino, V. (1997). Social and psychological factors affecting spontaneous second language use during study abroad. Unpublished PhD Dissertation, Bryn Mawr College, Bryn Mawr, PA.

Pellegrino, V. (1998). Student perspectives on language learning in a study abroad context. Frontiers, 4 (Fall), 91-120.

Pérez-Vidal, C., \& Juan-Garau, M. (2009). The effect of Study Abroad (SA) on written performance. EUROSLA Yearbook, 9(1), 269-295.

Perkins, P. R. (2004). International students' social contact on an American university campus: A focus on American-International student friendships. The University of Alabama, Tuscaloosa, AL.

Polanyi, L. (1995). Language learning and living abroad: Stories from the field. In B. F. Freed (Ed.), Second language acquisition in a study abroad context (pp. 271-291). Amsterdam, The Netherlands: John Benjamins Co.

Rivers, W. P. (1998). Is being there enough? The effects of homestay placements on language gain during study abroad. Foreign Language Annals, 31(4), 492-500.

Rohs, F. R., \& Langone, C. A. (1997). Increased accuracy in measuring leadership impacts. Joural of Leadership Studies, 4(1), 150-158. 
Scott, J. (2000). Social network analysis: A handbook. Los Angeles: Sage Publications.

Segalowitz, N., \& Ryder, A. (2006). Montreal Index of Linguistic Integration (MILI). Unpublished questionnaire, Concordia University, Montreal, Quebec, Canada. Concordia University.

Siegal, M. (1995). Individual differences and study abroad: Women learning Japanese in Japan. In B. F. Freed (Ed.), Second language acquisition in a study abroad context (pp. 225-244). Amsterdam, The Netherlands: John Benjamins Co.

Teichler, U., \& Maiworm, F. (1997). The ERASMUS experience: Major findings of the ERASMUS evaluation research. Luxemburg: Office for Official Publications of the European Countries.

Whitworth, K. F. (2006). Access to learning during study abroad: The roles of identity and subject positioning. The Pennsylvania State University. Wilkinson, S. (1996). Foreign language conversation and the study abroad transition: A case study. Dissertation Abstracts International, A: The Humanities and Social Sciences, 57(1), 140-A.

Wilkinson, S. (1998a). On the nature of immersion during study abroad: Some participant perspectives. Frontiers: The Interdisciplinary Journal of Study Abroad, IV(Fall), 121-138.

Wilkinson, S. (1998b). Study abroad from the participants' perspective: A challenge to common beliefs. Foreign Language Annals, 31(1), 23-39. Wilkinson, S. (2002). The Omnipresent Classroom during Summer Study Abroad: American Students in Conversation with Their French Hosts. Modern Language Journal, 86(2), 157-173.

Yager, K. (1998). Learning Spanish in Mexico: The Effect of Informal Contact and Student Attitudes on Language Gain. Hispania, 81(4), 898-913. 